\title{
Identification and Quantification of Corn, Soybean and Cotton Genetically Modified by Real Time PCR
}

\author{
Haiko Enok Sawazaki1, Aildson Pereira Duarte1, Milton Geraldo Fuzatto1, \\ Eduardo Sawazaki ${ }^{1}$, Silvio Henrique Reginato Grandi², Jéssica Funari de Ponte², \\ Larissa Nogueira ${ }^{2}$ \\ ${ }^{1}$ APTA-Instituto Agronômico de Campinas (IAC), Campinas, Brazil \\ ${ }^{2}$ Trainee with Scholarship-IAC, Campinas, Brazil \\ Email: henok@iac.sp.gov.br
}

Received 27 March 2015; accepted 19 July 2015; published 22 July 2015

Copyright (C) 2015 by authors and Scientific Research Publishing Inc.

This work is licensed under the Creative Commons Attribution International License (CC BY).

http://creativecommons.org/licenses/by/4.0/

c) $\underset{\mathrm{EY}}{\mathrm{O}}$ Open Access

\begin{abstract}
In order to obtain a cheaper method for quantification of transgenic events in corn, soybeans and cotton, primers for real time PCR have been developed and optimized, with fluorescent BRYT Green system. The DNA was extracted from grains, with and without event, by CTAB method. The following events have been studied for corn: MON810, Bt11, MON89034, GA21, TC1507, NK603, MIR162, PR03; Soybean: GTS-40-3-2, MON87701; MON89788; for cotton: MON1445, MON531, LLCotton25, 281-24-236; 3006-210-23, GHB614, T304-40; GHB119, MON15985, MON88913, besides the respective primers for the endogenous genes of corn, soybean and cotton. The sensitivity was $0.057 \%$, the coefficient of linearity $R^{2}$ ranged from 0.98 to 0.99 and the efficiency of PCR 0.9 to 1.1. The quantification of events ranged from 92 to 115, with a relative error (RE) from 2 to $18 \%$, and a variance of 0.33 to 3.0. The precision acceptance criterion was observed for all analyses, as well the repeatability and reproducibility. As it was found that the measurement of accuracy and reproducibility were within the international acceptance criterion, it may infer the robustness of the methodology. Therefore, the results from replicates with two different technicians, and validation of results by comparison with those obtained by Eurofins Brazil, showed the possibility of specific and quantitative analysis of transgenic events with a cheaper method with sensitivity, repeatability and robustness.
\end{abstract}

\section{Keywords}

Transgenic Events, Quantification, Corn, Soybean, Cotton 


\section{Introduction}

The detection and quantification of genetically modified organism (GMO) are required by the countries to which Brazil exports food to. In Brazil, the limit of 1\% of GMOs is determined by 4680 Decree of 24 April 2003 [1] being GM labeling mandatory for food with presence above the limit of $1.0 \%$ of the final product. Corn, soybean and cotton are genetically modified to express foreign proteins to manage lepidopteran insect pests or to allow application of herbicides (glyphosate and/glufosinate) to control weeds.

The technique of quantitative analysis performed by event-specific real-time PCR, using Taqman is, the official method used in Europe, whose methods are validated by the European Union Reference Laboratory for GM Food and Feed (EU-RL GMFF at http://gmo-crl//.jrc.ec.europa.eu/statusofdoss.htm) and found in the JRC Compendium of Reference Methods for GMO analysis (JRC-ISO/FDIS).

The methodology with fluorescence system Taqman uses probes, in addition to the primers. The fluorescence system BRYT Green has the same principle of detection of PCR products. The advantage of this system is that the fluorescent reagent is cheaper than the Taqman (there are similar dyes as BRYT Green, Evagreen, SYBR Green and the offer of SYBR is high due to be produced by several companies in several countries) and requires no fluorescent probe. The disadvantage is that it can lead to false positive signal when binding to non-specific DNA double strand occurs, requiring the development of specific primer and optimization of reaction to amplify only the desired band.

The objective is to obtain a cheaper and efficient methodology for diagnosis and quantification of transgenic events using BRYT Green (SYBR) in real time PCR, for corn, soybeans and cotton, through the development of specific primers, with efficiency PCR in the range 99\% - 101\%, in order to facilitate the processes of agribusiness, since the detection and quantification of genetically modified organism (GMO) is required in almost all countries which Brazil exports food to.

For validation, the same DNA samples tested were quantified by Eurofins Brazil (part of the international laboratory which uses certified material and Taqman system). The best reaction conditions were then used in three assays to quantify the event, with the same analyst, and with a different analyst to evaluate the linearity, sensitivity, limit of detection, limit of quantification, accuracy, repeatability, reproducibility and robustness.

\section{Materials and Methods}

\subsection{Material and Events}

The events studied are shown in Table 1, the samples are shown in Table 2. After homogenization and grinding the sample, two hundred milligrams were used for DNA extraction by the method of bromide Cetyltrimethyl ammonium bromide (CTAB) as in [2]. The integrity and quantification of extracted DNA were observed using electrophoresis.

The purity of DNA was checked with the inhibition test performed with standard curves from a sample called "undiluted" using endogenous primers, i.e., the values of Ct (Threshold cycle: is the cycle in which each amplification curve crosses the threshold line, serving as a basis for comparison between samples; threshold is the detection threshold set by the user to analyze results at the end of a real-time PCR) of the endogenous gene amplification, were compared with the data extrapolated from the calibration curve. The criteria accepted by the Community Reference Laboratory for Genetically Modified Food and Feed (CRL-GMFF) [3] for the absence of PCR inhibitors is when the average difference $(\Delta \mathrm{Ct})$ between the measured value and the extrapolated $\mathrm{Ct}$ value for the "undiluted" sample is $<0.5$ cycles and the "slope" between -3.6 and -3.1 .

\subsection{Real Time PCR}

Specific primers designed from the region 5' or 3' end of the genome/insert interaction, with the Primer 3 program were optimized. The initiators of endogenous reference genes for corn, soybean and cotton, respectively, adh1 (ADH, maize alcohol dehydrogenase), lec (LEC, lecithin) and adhC (ADH, cotton alcohol dehydrogenase $\mathrm{C}$ gene) were used. The reactions and conditions were optimized for the 7500 Fast Real Time Applied Biosystems (APPLIED BIOSYSTEMS) to a volume of $15.0 \mu \mathrm{l}$ with $7.5 \mu \mathrm{l}$ of the mix BRYT ${ }^{\mathrm{TM}}$ Green (Go Taq qPCR Master Mix of PROMEGA).

The efficiency of PCR standard curve was calculated from the value of "slope" being:

$$
\text { PCR efficiency }=\mathrm{E}=10^{(-1 / \text { slope })}-1
$$


Table 1. GM events for corn, soybean and cotton with their respective proteins.

\begin{tabular}{|c|c|c|c|}
\hline Event & Tradename & Protein & Plant \\
\hline GTS-40-3-2 & RR (Roundup Ready) & CP4-EPSPS (glyphosate) & soybean \\
\hline MON87701xMON89788 & Intacta RR2 PRO & CP4-EPSPS (glyphosate), Cry1Ac & soybean \\
\hline MON87701 & Bt soybean & Cry1Ac & soybean \\
\hline MON89788 & Roundup RR2 & (glyphosate) CP4-EPSPS & soybean \\
\hline MON810 & YieldGard (YG) & Cry1Ab & corn \\
\hline Bt11 & Agrisure or TL* & Cry1Ab, PAT(glufosinate) & corn \\
\hline GA21 & Roundup Ready or TG* & mEPSPS (glyphosate) & corn \\
\hline NK603 & Roundup Ready® 2 & CP4-EPSPS and CP4-EPSPS L214P & corn \\
\hline MON89034 & PRO & Cry1A.105, Cry2AB2 & corn \\
\hline TC1507 & HerculexI-LL & Cry1F, PAT & corn \\
\hline MIR162 & TL-Viptera & Vip3Aa20 & corn \\
\hline MON810xNK603 & YG/RR2 & Cry1Ab, CP4 EPSPS, CP4 EPSPS L214P & corn \\
\hline TC1507xNK603 & $\mathrm{Hx} \mathrm{RR}^{\prime} 2$ & Cry1F, PAT, CP4 EPSPS & corn \\
\hline MON89034xNK603 & VT PRO2 & $\begin{array}{l}\text { CP4 EPSPS and CP4 EPSPS L214P, Cry1A.105, } \\
\text { Cry2Ab2 }\end{array}$ & corn \\
\hline Bt11xMIR162xGA21 & Viptera3 & Cry1Ab, Vip3Aa20, CP4 EPSPS e mEPSPS, PAT & corn \\
\hline MON89034xTC1507xNK603 & Power Core (PW) & $\begin{array}{l}\text { CP4-EPSPS, CP4-EPSPS L214P, PAT, Cry1F, } \\
\text { Cry1A.105, Cry2Ab2 }\end{array}$ & corn \\
\hline MON89034xMON88017 & VT PRO3 & Cry1A.105, Cry2AB2, Cry3Bb 1, CP4-EPSPS & \\
\hline MON531 & Bolgard I & Cry1Ac & cotton \\
\hline MON1445 & Roundup Ready Cotton & CP4-EPSPS & cotton \\
\hline LLCotton25 & Liberty Link & PAT & cotton \\
\hline MON531 x MON1445 & Bolgard I Roundup Ready & Cry1Ac, CP4-EPSPS & cotton \\
\hline $281-24-236$ x 3006-210-23 & Widestrike & Cry11F, Cry1Ac, PAT & cotton \\
\hline GHB614 & Glytol & 2mEPSPS & cotton \\
\hline T304-40 x GHB119 & Twinlink & Cry1Ab, Cry2A2, PAT & cotton \\
\hline $\begin{array}{c}\text { GHB614 x T304-40 x GHB } 119 \text { x } \\
\text { LLCotton } 25\end{array}$ & Glytol xLLx TwinLink (GLT) & Cry1Ab, Cry2Ae, 2mePSPS, PAT & cotton \\
\hline MON15985 & Bolgard II & Cry2Ab2, Cry1Ac & cotton \\
\hline MON88913x & Round Up Ready Flex & CP4-EPSP & cotton \\
\hline MON 15985 x MON 88913 & BolgardII RR Flex & Cry1Ac, Cry2Ab2, CP4-EPSPS & cotton \\
\hline
\end{tabular}

${ }^{*}$ TL means lepidopteran tolerance and TG glyphosate tolerance.

\subsection{Optimization of Standard Curve}

Standard curves were performed for event and endogenous reference. For each sample, the amount of the event was determined from curves standard, and reference.

The standard curve was taken with $20 \%, 2.86 \%, 0.41 \%$ and $0.057 \%$ of DNA event, mixed with none event, for reaction of 100 ng DNA.

The absolute number of copies of the standard curve was determined by dividing the weight of DNA (nano- 
Table 2. Samples of corn, soybean and cotton with and without transgenic event.

\begin{tabular}{|c|c|c|c|c|c|}
\hline \multicolumn{6}{|c|}{ Plant } \\
\hline Samplename & Tradename & Event & Samplename & Tradename & Event \\
\hline \multicolumn{6}{|c|}{ Corn } \\
\hline AG 8061 & conventional & - & DKB 350 & conventional & - \\
\hline AG 8088 & conventional & - & DKB 390 & conventional & - \\
\hline AG8088 YG & YieldGard & MON810 & DKB350 YG & YieldGard & MON810 \\
\hline AG 8061 PRO & PRO & MON89034 & DKB390 YG & YieldGard & MON810 \\
\hline AG8088 PRO2 & PRO2 & MON89034XNK603 & DKB350 PRO & PRO & MON89034 \\
\hline AG8088YGRR2 & YG RR2 & MON810X NK603 & DKB390 PRO2 & PRO2 & MON89034XNK603 \\
\hline AG8780PRO3 & VT PRO3 & $\begin{array}{c}\text { MON89034xMON } \\
88017\end{array}$ & DKB290PRO3 & VT PRO3 & $\begin{array}{c}\text { MON89034xMON } \\
88017\end{array}$ \\
\hline 2B707 & conventional & - & STATUS & conventional & - \\
\hline 2B710 & conventional & - & IMPACTO & conventional & - \\
\hline \multirow[t]{2}{*}{ 2B587 } & conventional & - & TRUCK & conventional & - \\
\hline & & & STATUS TL & $\mathrm{TL}$ & Bt11 \\
\hline 2B710 Hx & Herculex ${ }^{\circledR}$ I & TC1507 & IMPACTO TL & $\mathrm{TL}$ & Bt11 \\
\hline 2B707 Hx & Herculex $®$ I & TC1507 & TRUCK TL & $\mathrm{TL}$ & Bt11 \\
\hline 2B587 Hx & Herculex ${ }^{\circledR} \mathrm{I}$ & TC1507 & STATUS VIP & Viptera-MIR162 & MIR162 \\
\hline 2B710 HR & Herculex ${ }^{2}$ I RR2 & TC1507xNK603 & IMPACTO VIP & Viptera-MIR162 & MIR162 \\
\hline \multirow[t]{3}{*}{$\begin{array}{l}\text { MON89034xTC1507x } \\
\text { NK603 }\end{array}$} & Powercore* Pw & $\begin{array}{c}\text { MON89034xTC1507xN } \\
\text { K603 }\end{array}$ & TRUCK VIP & Viptera-MIR162 & MIR162 \\
\hline & & & Maximus VIP & TLViptera & Bt11XMIR162 \\
\hline & & & Viptera 3* & TL TG Viptera & $\begin{array}{c}\text { Bt11XGA21XMIR16 } \\
2\end{array}$ \\
\hline $20 \mathrm{~A} 78$ & conventional & - & $30 \mathrm{~F} 35$ & conventional & - \\
\hline 30A37 & conventional & - & & & \\
\hline 20A78 HX & Herculex ${ }^{\circledR} \mathrm{I}$ & TC1507 & 30F35 H & Herculex ${ }^{\circledR} \mathrm{I}$ & TC1507 \\
\hline 30A37 HX & Herculex ${ }^{\circledR}$ I & TC1507 & 30F35 Y & YieldGard & MON810 \\
\hline \multicolumn{6}{|c|}{ Soybean } \\
\hline Foscarin & conventional & - & 95R51 & Roundup Ready & GTS-40-3-2 \\
\hline NS 5959 IPRO & Intacta RR2 PRO* & $\begin{array}{c}\text { MON87701xMON8978 } \\
8\end{array}$ & NS 7237 IPRO & Intacta RR2PRO* & $\begin{array}{c}\text { MON87701xMON89 } \\
788\end{array}$ \\
\hline \multicolumn{6}{|c|}{ Cotton } \\
\hline DP 604 BG & BollgardI & MON531 & FM 951 LL & Liberty Link & LL Cotton25 \\
\hline NUOPAL & BollgardI & MON531 & FM 966 LL & Liberty Link & LL Cotton25 \\
\hline NUOPAL RR & BollgardI X RR & $\begin{array}{l}\text { MON531 X Roundup } \\
\text { Ready }\end{array}$ & FM 980 GLT & $\begin{array}{l}\text { Glytol x LL x } \\
\text { TwinLink }\end{array}$ & $\begin{array}{c}\text { GHB614 x } \\
\text { LLcotton25 x T304-40 } \\
\text { x GHB119 }\end{array}$ \\
\hline DP 555 BGRR & BollgardI X RR & $\begin{array}{l}\text { MON531 X Roundup } \\
\text { Ready }\end{array}$ & FM 940 GLT & $\begin{array}{l}\text { Glytol x LL x } \\
\text { TwinLink }\end{array}$ & $\begin{array}{c}\text { GHB614 x LL x } \\
\text { T304-40 x GHB119 }\end{array}$ \\
\hline FMT 705I & conventional & - & FM 913 GLT & $\begin{array}{l}\text { Glytol x LL x } \\
\text { TwinLink }\end{array}$ & $\begin{array}{l}\text { GHB614 x LL x } \\
\text { T304-40 x GHB119 }\end{array}$ \\
\hline FMT 707 & conventional & - & FM 975 WS & Widestrike & $\begin{array}{l}281-24-236 x \\
3006-210-23\end{array}$ \\
\hline FMT 709 & conventional & - & IMA 5672BG2RF & BollgardII RR Flex & $\begin{array}{c}\text { MON88913 x MON } \\
15985\end{array}$ \\
\hline BRS 269 & conventional & - & IMA 5675BG2RF & BollgardII RR Flex & $\begin{array}{c}\text { MON88913 x MON } \\
15985\end{array}$ \\
\hline
\end{tabular}

"Powercore was provided by Down Agroscience, Viptera3 by Syngenta Seeds andIntactaRR2PRO by Nidera Seeds. 
grams) by the published average IC value as in [4] of genome DNA, for corn (2725 picograms), soybean (1.13 pg) and cotton $(2.33 \mathrm{pg})$. Table 3 shows the values of copy number of the event in points of standard curve for samples of corn, soybean and cotton

For normalization of quantification of an event in a sample, the event copy number was divided by the copy number of the endogenous gene and multiplied by 100 to yield the percentage value:

$$
\% \mathrm{GM}=\frac{\text { event copy number }}{\text { copy number of endogenous gene }} \times 100
$$

\subsection{Validation}

The evaluation of linearity, working range, sensitivity, and limit of detection, limit of quantification, repetitiveness, precision, reproducibility, accuracy, and robustness was made according to the parameters defined by CRLGMFF [3] and DOQ-CGCRE-008-INMETRO [5]. CRL-GMFF [3] gives recommendations to evaluate and validate analytical methods of GMO, according with the Commission regulation (EC) No. 1829/2003 in Europe.

The linear range of work established when the method is linear with an acceptable level of accuracy and precision, is accepted to be $1 / 10$ and at least 5 times the concentration required by legislation (JRRC 56609-Mon810). In Brazil, the GMO limit is $1 \%$, determined by Decree 4680 [1]. Therefore, working range must be from $0.1 \%$ to at least $5 \%$.

The parameter used for the sensitivity is the slope, being the acceptance criterion for the standard curve, the average value in the range of -3.1 to -3.6 .

By law, the LOQ (limit of quantification) is less than $1 / 10^{\text {th }}$ and the LOD (limit of detection), at least $1 / 20^{\text {th }}$ of the threshold value; as in Brazil, the limit of GMOs is $1 \%$ the limits correspond to $0.1 \%$ and $0.05 \%$.

The precision has been achieved by the repeatability and reproducibility. The repeatability of identification by three replicates for each measurement performed in the same analysis, determined by the coefficient of linearity $\mathrm{R}^{2}$ (correlation coefficient of a standard curve obtained by linear regression analysis) which should be $\geq 0.98$, and the limit of repeatability $\left(r=t \infty \sqrt{2} \cdot S_{r}\right)$. To a 95\% significance level: $r=2.8 \cdot S_{r}$, where $S_{r}$ is the standard deviation associated with the Ct readings for the same analysis.

The reproducibility was verified by analyses with two different technicians in different days, using the same apparatus under the same conditions of temperature and time previously optimized for each primer; the differences in the percentage of quantitation between the analyses must not be greater than the reproducibility limit $\mathrm{R}$ $\left(\mathrm{R}=\mathrm{t} \infty \sqrt{2} \cdot \mathrm{S}_{\mathrm{R}}\right.$ ); or, for a 95\% significance level: $\mathrm{R}=2.8 \cdot \sqrt{\mathrm{S}_{\mathrm{R}}^{2}}$ (where $\mathrm{S}_{\mathrm{R}}^{2}=$ variance of reproducibility of quantification percentage detected by the two technicians).

The accuracy criterion (agreement between the result of the laboratory and the reference value) defined as $\pm 25 \%$ as in [3], requires a reference value. The value used as a reference was the analysis of Eurofins in Brazil (from Eurofins Agroscience Services), although it was not possible to have all events analyzed. The same samples used for quantification studies were analyzed by Eurofins for validation and comparison of studied methodology. The relative error (RE) was expressed as a percentage by means of the expression:

$$
\mathrm{RE}=(\mathrm{Xlab}-\mathrm{Xv}) / \mathrm{Xv} \times 100
$$

where: $\mathrm{Xlab}=$ value obtained experimentally or arithmetical average of obtained values; $\mathrm{Xv}=$ value accepted as true.

Table 3. Values and percentage of the number of copies of the events in the standard curve for samples of corn, soybean and

\begin{tabular}{|c|c|c|c|c|}
\hline Sample copies & S1/dilution\% & S2/dilution\% & S3/dilution\% & S4/dilution\% \\
\hline Corn genome & 36697 & 5242 & 749 & 107 \\
\hline Corn event & $7339 / 20$ & $1048 / 2.85$ & $149 / 0.40$ & $21 / 0.057$ \\
\hline Soybean genome & 88495 & 12642 & 1806 & 258 \\
\hline Soybean event & $17699 / 20$ & $2528 / 2.85$ & $361 / 0.40$ & $51.6 / 0.057$ \\
\hline Cotton genome & 42918 & 6131 & 876 & 125 \\
\hline Cotton event & $8584 / 20$ & $1226 / 2.85$ & $175 / 0.40$ & $25 / 0.057$ \\
\hline
\end{tabular}
cotton. 
The robustness by the measures of reproducibility and accuracy was inferred within the limits stipulated by CRL-GMFF [3] that shall not deviate more than $\pm 30 \%$.

\section{Results and Discussion}

\subsection{DNA Extraction Test}

The performance of the extraction of DNA, which is essential for the success of PCR analysis, was tested for the presence of inhibitors. By the inhibitor test, no samples of corn, soybean and cotton, showed for the average difference $(\Delta \mathrm{Ct})$ between the measured value and the extrapolated $\mathrm{Ct}$ value, $\Delta \mathrm{Ct}>0.5$ cycle, indicating the significant absence of inhibitors.

\subsection{Specificity Analysis}

The specificity of the primers developed in the region of genome/insert interaction, was tested by using a reaction of $15.0 \mu \mathrm{l}$, with $20 \mathrm{ng}$ of DNA on "FAST" method (initial heating at $95^{\circ} \mathrm{C} / 2 \mathrm{~min}$ followed by 40 cycles of denaturation, annealing and extension at $95^{\circ} \mathrm{C} / 10 \mathrm{~s}$ and $\left.60^{\circ} \mathrm{C} / 30 \mathrm{~s}\right)$. All analysis showed amplification when performed with specific primer of Table 5 and were completely specific in relation to all events of the other samples studied. Also the dissociation peak showed practically only the correspondent peak for the studied event.

The concentration of primers (forward and reverse) used were the same or almost the one used in the quantification analysis (Table 4).

Table 4. PCR conditions of transgenic events in corn, soybeans and cotton and the amount used of primers of event or gene to obtain the standard curve.

\begin{tabular}{|c|c|c|}
\hline Transgenic event/sample & Annealing and extension & Quantity of primer (nM) forward/reverse \\
\hline Bt11/corn & at $60^{\circ} \mathrm{C} / 1 \mathrm{~min}$ and $20 \mathrm{~s}$ & $433 / 433$ \\
\hline TC1507/corn & at $60^{\circ} \mathrm{C} / 1 \mathrm{~min}$ and $10 \mathrm{~s}$ & $400 / 400$ \\
\hline MIR 162/corn & at $60^{\circ} \mathrm{C} / 1 \mathrm{~min}$ & $367 / 367$ \\
\hline NK 603/corn & at $60^{\circ} \mathrm{C} / 1 \mathrm{~min}$ and $30 \mathrm{~s}$ & 333/333 \\
\hline MON810/corn & at $60^{\circ} \mathrm{C} / 1 \mathrm{~min}$ and $30 \mathrm{~s}$ & $433 / 433$ \\
\hline MON89034/corn & at $60^{\circ} \mathrm{C} / 1 \mathrm{~min}$ and $30 \mathrm{~s}$ & $500 / 500$ \\
\hline GA21/corn & at $60^{\circ} \mathrm{C} / 30 \mathrm{~s}$ & $433 / 433$ \\
\hline MON88017/com & at $60^{\circ} \mathrm{C} / 1 \mathrm{~min}$ & $200 / 200$ \\
\hline GTS-40-3-2/soybean & at $60^{\circ} \mathrm{C} / 1 \mathrm{~min}$ & $300 / 300$ \\
\hline MON87701/soybean & at $60^{\circ} \mathrm{C} / 1 \mathrm{~min}$ & $200 / 200$ \\
\hline MON89788/soybean & at $60^{\circ} \mathrm{C} / 1 \mathrm{~min}$ & $266 / 266$ \\
\hline MON531/cotton & at $60^{\circ} \mathrm{C} / 50 \mathrm{~s}$ & $267 / 267$ \\
\hline MON1445/cotton & at $60^{\circ} \mathrm{C} / 1 \mathrm{~min}$ & $233 / 233$ \\
\hline LLcoton25/cotton & at $60^{\circ} \mathrm{C} / 1 \mathrm{~min}$ & $133 / 133$ \\
\hline 281-24-236 /cotton & at $60^{\circ} \mathrm{C} / 50 \mathrm{~s}$ & $200 / 200$ \\
\hline 3006-210-23/cotton & at $60^{\circ} \mathrm{C} / 1 \mathrm{~min}$ & $300 / 300$ \\
\hline GHB 614/cotton & at $60^{\circ} \mathrm{C} / 1 \mathrm{~min}$ & $167 / 167$ \\
\hline T304-40/cotton & at $60^{\circ} \mathrm{C} / 50 \mathrm{~s}$ & $167 / 167$ \\
\hline GHB 119/cotton & at $60^{\circ} \mathrm{C} / 50 \mathrm{~s}$ & $133 / 133$ \\
\hline MON15980/cotton & at $60^{\circ} \mathrm{C} / 1 \mathrm{~min}$ & $266 / 266$ \\
\hline MON88913/cotton & at $60^{\circ} \mathrm{C} / 1 \mathrm{~min}$ & $200 / 200$ \\
\hline Adh/corn & at $60^{\circ} \mathrm{C} / 1 \mathrm{~min}$ & $133 / 133$ \\
\hline Lec/soybean & at $60^{\circ} \mathrm{C} / 1 \mathrm{~min}$ & 333/333 \\
\hline AdhC/cotton & at $60^{\circ} \mathrm{C} / 1 \mathrm{~min}$ & $133 / 133$ \\
\hline
\end{tabular}


Table 5. Specific primers developed by laboratory with original annealing temperature $(\mathrm{T})$ in ${ }^{\circ} \mathrm{C}$, amplification length (A) in base pairs and PCR efficiency (E) for the transgenic events or endogenous genes in corn, soybean, and cotton.

\begin{tabular}{|c|c|c|c|c|}
\hline Event or gene/Trade name & Forward Primer 5'-3'/Reverse Primer 5'-3' & $\mathbf{T}$ & A & $\mathbf{E}$ \\
\hline MON810/YieldGard & $\begin{array}{l}\text { 121YG: CTAACGTTTAACATCCTTTGCCATTGC } \\
\text { 242YG: TCTTCAACGATGGCCTTTCCTTTAT }\end{array}$ & 51 & 122 & 1.07 \\
\hline Bt11/TL & $\begin{array}{l}\text { 52Bt11: GCGGAACCCCTATTTGTTTAT } \\
\text { 123Bt11: AATCCAAGAATCCСTCCATGA }\end{array}$ & 57 & 72 & 1.09 \\
\hline MON89034/PRO & $\begin{array}{l}\text { 181PRO: AAAGGATGGTAATGAGTATGATGGA } \\
\text { 302PRO: TTATAATAACGCTGCGGACATCTA }\end{array}$ & 57 & 122 & 1.02 \\
\hline TC1507/Herculex I & $\begin{array}{l}\text { 81Hx:TTC ATC GTA AGA AGA CAC TCA GTA } \\
\text { 174Hx: AAT GCG TCA AAT ATC TTT GC }\end{array}$ & 56 & 94 & 1.03 \\
\hline MIR162/Viptera & $\begin{array}{l}144 \text { MIR: GCGCGCGGTGTCATCTATGTTACTA } \\
\text { 222MIR: CTTCAGACCATGGCGGACGTTTT }\end{array}$ & 56 & 79 & 0.9 \\
\hline GA21/TG & $\begin{array}{l}\text { 15GA21: GTCA GCA ACG GCG GAA GGAT } \\
\text { 103GA21: AGC TTG ACG GTG CCG GAG AT }\end{array}$ & 59 & 89 & 0.98 \\
\hline NK603/Roundup Ready 2 & $\begin{array}{l}\text { 72NK: TCT CAA GCA TAT GAA TGA CCT CGA GTA } \\
\text { 190NK: GAAGAGATAACAGGATCCACTCAAACACTA }\end{array}$ & 50 & 119 & 0.92 \\
\hline MON88017/PRO3 & $\begin{array}{l}\text { 28PRO3: AGC AGG ACC TGC AGA AGC TA } \\
\text { 124PRO3: GTA TGC CGG AGT TGA CCA TC }\end{array}$ & 50 & 96 & 0.9 \\
\hline adh1/ADH & $\begin{array}{l}\text { 75ADH: TCGTTTCССАТСТСТTCСТССТT } \\
\text { 189ADH: TCССТCACCAGTTACGAAACCAA }\end{array}$ & 51 & 115 & 0.94 \\
\hline GTS-40-3-2/Roundup Ready & $\begin{array}{l}\text { 124RRF: GCATTTCATTCAAAATAAGATCATACATACAG } \\
\text { 225RRR: TTTATCGCAATGATGGCATTTGTAG }\end{array}$ & 50 & 102 & 0.9 \\
\hline MON87701/INTACTA RR2 PRO & $\begin{array}{l}\text { 86M87701: TTGGTGATATGAAGATACATGCTTAG } \\
\text { 217M87701: GCT GCA GGA ATT CGA TAT CAA }\end{array}$ & 57 & 132 & 0.92 \\
\hline MON89788/INTACTA RR2 PRO & $\begin{array}{l}\text { 113M89788: TCC CGC TCT AGC GCT TCA AT } \\
\text { 247M89788:GCA GGA CCT GCA GAA GCT TGA T }\end{array}$ & 55 & 135 & 1.1 \\
\hline lec1/LEC & $\begin{array}{l}\text { 187Lec: TGGTCGCGCCCTCTACTC } \\
\text { 257Lec: GGCGAAGCTGGCAACG }\end{array}$ & 52 & 70 & 1.1 \\
\hline MON531/BollgardI & $\begin{array}{l}\text { 77BollgardI: TTG ATG TAC ACC AAA GAG AAA CC } \\
\text { 231BolgardI: CCT TGT AAA CGA TGT TAG TTT CC }\end{array}$ & 50 & 155 & 0.96 \\
\hline LLCotton25/Liberty link & $\begin{array}{l}\text { 194LL:CCC TCA AGG AAC TAT TCA ACT } \\
\text { 293LL: AAC TGT GCT GTT AAG CTC AGA }\end{array}$ & 60 & 100 & 0.9 \\
\hline MON1445/Roundup Ready & $\begin{array}{l}\text { 148MON1445: CTT GAT TGG AGT AAG ACG ATT CAG } \\
\text { 254MON1445: ACA ACA TGC ATC AAT CGA CCT }\end{array}$ & 50 & 158 & 0.96 \\
\hline 281-24-236/Widestrike & $\begin{array}{l}\text { 138Widecry1F: TGATCCATGTAGATTTCCCTTACT T } \\
\text { 257Widecry1F: CAAATTAATACCTTAGGGACAATGC }\end{array}$ & 49 & 119 & 0.9 \\
\hline
\end{tabular}




\begin{tabular}{|c|c|c|c|c|}
\hline \multicolumn{5}{|l|}{ Continued } \\
\hline \multirow{2}{*}{ 3006-210-23/Widestrike } & 194Widecry1Ac:ATT GAG TAT GAT GTC CGG GAA A & \multirow{2}{*}{45} & \multirow{2}{*}{60} & \multirow{2}{*}{0.92} \\
\hline & 253Widecry1Ac: CCATATTGACCATCATACTCATTGC & & & \\
\hline \multirow{2}{*}{ adhC/ADHC } & 89AdhC: CCA TCT TTG CTT GCA GGT TTT & \multirow{2}{*}{50} & \multirow{2}{*}{111} & \multirow{2}{*}{0.9} \\
\hline & 199AdhC: ACAATAACTTACCGCAAGACCTACAG & & & \\
\hline \multirow{2}{*}{ GHB614/Glytol } & 156GHB614: CAC TTG GAA CGA CTT CGT TT & \multirow{2}{*}{51} & \multirow{2}{*}{145} & \multirow{2}{*}{0.96} \\
\hline & 300GHC314: CCA TGC CTC GAC TCA TAT TT & & & \\
\hline \multirow{2}{*}{ T304-40/TwinLink/ } & 80T304:CGC AAA CTA GGA TAA ATT ATCG & \multirow{2}{*}{45} & \multirow{2}{*}{73} & \multirow{2}{*}{0.9} \\
\hline & 152T304: CTA GAT CTT GGG ATA ACT TGA AAA & & & \\
\hline \multirow{2}{*}{ GHB119/TwinLink } & 74GHB119: AAAATCCAGTACTAAAATCCAGATCAT & \multirow{2}{*}{48} & \multirow{2}{*}{103} & \multirow{2}{*}{0.92} \\
\hline & 176GHB119: AAGTATTAGAAATTGCGTGACTCAAA & & & \\
\hline \multirow{2}{*}{ MON15985/Bollgard II } & 104MON15985F: CGC GGT GTC ATC TAT GTT ACTA & \multirow{2}{*}{51} & \multirow{2}{*}{91} & \multirow{2}{*}{0.98} \\
\hline & 194MON15985R: GCT AAA TGG ATGGGA TTT CAG & & & \\
\hline \multirow{2}{*}{ MON88913/Round Up Ready Flex } & 265MON88913F:TAC CCA TTA AGT AGC CAAA & \multirow{2}{*}{40} & \multirow{2}{*}{81} & \multirow{2}{*}{0.99} \\
\hline & 345MON88913R: CTA CCT TAA GAG AGT CAT GTT & & & \\
\hline
\end{tabular}

\subsection{Quantitative Analysis}

\subsubsection{Optimization of Real-Time PCR Conditions for Obtaining the Standard Curve}

The optimization of reaction conditions in real time pcr to obtain the standard curve was made using as parameter values required for validation by CRL-GMFF [3]. To this end, initially changes were tested in, primer concentration, temperature and time of annealing and extension time. Lower annealing temperature or longer time of annealing and extension can increase the fluorescence signal as it facilitates the annealing or amplification in some cases, however, may increase non-specific amplification. When the dissociation present more than one peak, indicating non-specific annealing, or even curve with the "shoulder" indicating not optimized reaction, the annealing temperature was increased and/or the concentrations of the primers decreased. Later, it was verified that is possible to reduce the time of reaction when the amount of primer was increased. Therefore, it was altered the conditions that requested a long time of reaction by increasing the amount of primer and using the same temperature for annealing and extension.

\subsubsection{Real Time PCR}

The reactions and conditions optimized for the 7500 Fast Real Time (APPLIED BIOSYSTEMS) to a volume of $15.0 \mu$ with $7.5 \mu$ l of the mix BRYT ${ }^{\mathrm{TM}}$ Green (Go Taq qPCR Master Mix of PROMEGA) used 133 - $500 \mathrm{nM}$ of primer, with one step of $95^{\circ} \mathrm{C}$ for 2 min followed by 40 cycles of denaturation at $95^{\circ} \mathrm{C}$ for $15 \mathrm{sec}$, annealing and extension at $60^{\circ} \mathrm{C}$ for 50 to $90 \mathrm{sec}$.

Table 4 shows for each transgenic event studied in corn, soybean, and cotton, the amount of primer used in the reactions optimized to obtain the standard curve of each event or endogenous gene and the annealing and extension conditions.

Table 5 shows the best primers developed in the laboratory for the studied events with data used in the standard curve, as the original annealing temperature in ${ }^{\circ} \mathrm{C}(\mathrm{T})$, amplification length in base pairs (A) and PCR efficiency (E).

The regression curves obtained for all events showed the coefficient of linearity $\mathrm{R}^{2}$ from 0.98 to 0.99 with Cts from 21.04 to 29.62 and 24.59 to 33.67, and variation of PCR efficiencies from 0.9 to 1.1. Regarding the curves of the endogenous gene made for each event, the $\mathrm{R}^{2}$ was almost 0.99 with efficiency of PCR, of 0.91 to 1.1. Those values are within the acceptance criterion of CRL-GMFF [3].

\subsection{Validation}

The linearity measured by PCR efficiency was from 0.9 to 1.01 indicating that the PCR product doubled every 
cycle when all reagents are also available, demonstrating the linear response.

The criterion working range $0.1 \%$ to until at least $5 \%$ was observed for the working range of $0.057 \%$ to $20 \%$ for the standard curve reaction using 100 ng DNA.

The values of LOD and LOQ $(0.1 \%$ and $0.05 \%)$ were practically followed, as the minimum used was $0.057 \%$. For all three analysis repetitions, the differences in the percentage of quantitation between the analyses were not greater than the repeatability limit and the $\mathrm{R}^{2}$ was $\geq 0.98$.

The variance of reproducibility of quantification for all events ( 0.33 to 3.0$)$ originated by the variance of the average results of repeating in three days or by different technicians, was lower than the limits of reproducibility and within the parameter set by CRL-GMFF [3] which is $\leq 30 \%$ showing the reproducibility.

The precision was observed for all analysis, as well the repeatability and reproducibility.

Table 6 shows data for validation by comparison the quantification average results (some analyses could not be made by Eurofins) obtained by Eurofins and our laboratory, with the average variance, the coefficient of linearity $\mathrm{R}^{2}$ and the relative error (RE). The variance is related to comparison of at least three laboratory analyses on different days.

The average quantification of laboratory tests carried at least three times on different days (at least two repetition tests with the same technician, and one with different technician) ranged from 92 to 115. By CRL-GMFF [3], the accuracy criterion is $\pm 25 \%$. The results of the relative errors (RE) methodologies between our laboratory and Eurofins (except for PRO, NK603 and GA21, which clearly have had problems because all samples were pure event), were from 2 to 18, below the stipulated by the CRL-GMFF [3], showing the accuracy of the laboratory

Table 6. Validation by comparison quantification percentage averages of laboratory and Eurofins.

\begin{tabular}{|c|c|c|c|c|c|c|}
\hline Sample & Event & $\begin{array}{c}\text { Laboratory } \\
\text { average }\end{array}$ & $\begin{array}{l}\text { Variance } \\
\text { average }\end{array}$ & $\mathrm{R}^{2}$ & Eurofins & $\mathrm{RE}$ \\
\hline DKB390PRO & MON89034 & 99 & 0.33 & 0.983 & 56 & 77 \\
\hline DKB390PRO2 & NK603 & 108 & 1.00 & 0.980 & 64 & 68 \\
\hline Impacto VIP & MIR162 & 111 & 0.33 & 0.996 & 94 & 18 \\
\hline 2B707Hx & TC1507 & 112 & 1.33 & 0.980 & 100 & 12 \\
\hline DKB390YG & MON810 & 102 & 2.33 & 0.983 & 100 & 2 \\
\hline Impacto TL & Bt11 & 112 & 0.57 & 0.980 & 100 & 12 \\
\hline VIP3 & GA21 & 103 & 1.33 & 0.983 & 47 & 119 \\
\hline AG8780PRO3 & MON88017 & 115 & 0.33 & 0.987 & & \\
\hline 95R51 & GTS-40-3-2 & 105 & 1.73 & 0.981 & 100 & 5 \\
\hline NS 7237 IPRO & MON89788 & 98 & 0.82 & 0.986 & 100 & 2 \\
\hline NS 5959 IPRO & MON87701 & 103 & 0.33 & 0.981 & 100 & 3 \\
\hline DP 604 BG & MON531 & 97 & 1.33 & 0.983 & & \\
\hline DP 555 BGRR & MON1445 & 99 & 3.00 & 0.983 & & \\
\hline FM 966 LL & LLcotton25 & 105 & 1.33 & 0.985 & & \\
\hline FM 975 WS & $3006-210-23$ & 92 & 2.08 & 0.996 & 100 & 8 \\
\hline FM 975 WS & $281-24-236$ & 95 & 2.33 & 0.998 & 100 & 5 \\
\hline FM 980GLT & GHB614 (Glytol) & 100 & 1.79 & 0.990 & & \\
\hline FM 940GLT & T304-40 (TwinLink) & 102 & 1.33 & 0.990 & & \\
\hline FM 913GLT & GHB119 (TwinLink) & 105 & 0.33 & 0.990 & & \\
\hline IMA 5672BG2RF (Bollgard II RR Flex) & MON15985 & 98 & 2.18 & 0.982 & & \\
\hline IMA 5672BG2RF (Bollgard II RR Flex) & MON88913 & 100 & 3.00 & 0.982 & & \\
\hline
\end{tabular}


method. As it was found according to the measurement of accuracy and reproducibility that the method was within the limits set by the CRL-GMFF [3], it may infer the robustness of the methodology.

\section{Conclusion}

For twenty-one transgenic events tested in corn, soybean and cotton have been observed for all developed primers, the overall specificity for each event, the limit of quantification (LOQ) of $0.057 \%$, PCR efficiency in the range 0.9 to 1.1. The $\mathrm{R}^{2}$ ranged from 0.98 to 0.99 . The relative error (ER) for quantification samples with events ranged from $2 \%$ to $18 \%$. The precision was observed for all analyses, as well the repeatability and reproducibility. As it was found according to the measurement of accuracy and reproducibility that the method was within the international acceptance criterion, it might infer the robustness of the methodology. Therefore, the results from replicates with two different technicians, and validation of results by comparison with those obtained by Eurofins Brazil, showed the possibility of specific and quantitative analysis of transgenic events with a cheaper method with sensitivity, repeatability and robustness.

\section{Acknowledgments}

To Fundação de Amparo a Pesquisa no Estado de São Paulo-FAPESP by financial support and TT-2 scholarship, and CNPq for the PIBIC scholarship.

\section{References}

[1] DOU (2003) Decree n ${ }^{\circ} 4680$ on April 2003. Section I, Diário Oficial da União, 2.

[2] Cardarelli, P., Branquinho, M.R., Ferreira, R.T.B., Cruz, F.P. and Gemal, A.L. (2005) Detection of GMO in Food products in Brazil: The INCQS Experience. Food Control, 16, 859-866. http://dx.doi.org/10.1016/i.foodcont.2004.07.010

[3] CRL-GMFF (2009) Definition of Minimum Performance Requirements for Analytical Methods of GMO Testing. http://gmo-crl.jrc.ec.europa.eu/doc/Min_Perf_Requirements_Analytical_methods.pdf

[4] Arumuganathan, K. and Earle, E.D. (1991) Nuclear DNA Content of Some Important Plant Species. Plant Molecular Biology Reporter, 9, 208-218. http://dx.doi.org/10.1007/BF02672069

[5] DOQ-CGCRE-008-INMETRO (2010) Orientação sobre validação de métodos de ensaios químicos. Revisão 03. 20 p. http://www.inmetro.gov.br/Sidoq/Arquivos/CGCRE/DOQ/DOQ-CGCRE-8_03.pdf 